\title{
EFFECTIVENESS FINANCIAL LITERACY TOWARD MAKING DECISION OF CONSUMER BEHAVIOR
}

\author{
Surono ${ }^{1}$ \\ Moh. Bahruddin ${ }^{2}$ \\ Ahmad Habibi ${ }^{3}$ \\ ${ }^{1}$ Universitas Airlangga, East Java, Indonesia \\ surono-2018@pasca.unair.ac.id,081358566651 ${ }^{1}$ \\ ${ }^{2}$ Universitas Islam Negeri Raden Intan Lampung, Lampung, Indonesia \\ mohbahruddin@radenintan.ac.id,08127201452² \\ ${ }^{3}$ Universitas Islam Negeri Raden Intan Lampung, Lampung, Indonesia \\ ahmadhabibi@radenintan.ac.id, 081584717447³
}

\begin{abstract}
Effectiveness Financial Literacy Toward Making Decision Of Consumer Behavior. This study aims to examine the effect of financial literacy on customer behavior. This research was conducted on the campus community of economics and business faculties of Islamic Islamic University of Lampung in 2013. The samples obtained were 41 of 496 people using slovin sampling. Analysis of the data used is quantitative descriptive using simple linear regression with the help of the statistical program spss 23 for windows. The results of the study stated that financial literacy has a positive and significant effect on consumer behavior in determining consumption decisions. Self-control is not enough to determine the right decision in consumption, so financial knowledge is needed in making effective decisions so that it can get maximum utility from the products consumed to improve welfare.
\end{abstract}

Key words: Consumer Behavior; Financial Literacy; Making Decision.

Abstrak: Efektivitas Literasi Keuangan Terhadap Perilaku Konsumen Dalam Membuat Keputusan. Penelitian ini mempunyai tujuan untuk menguji pengaruh literasi keuangan terhadap perilaku konsumen. Riset ini dilakukan pada masyarakat kampus fakultas ekonomi dan bisnis islam uin raden intan lampung tahun 2013. sampel yang diperoleh 41 dari 496 orang menggunakan pensamplingan slovin. Analisis data yang digunakan deskriptif kuantitatif menggunakan regresi linier sederhana dengan bantuan program statistic spss 23 for windows. Hasil penelitian menyatakan bahwa literasi keuangan berpengaruh positif dan signifikan terhadap perilaku konsumen dalam menentukan keputusan konsumsi. Self kontrol kurang cukup untuk menentukan keputusan yang tepat dalam berkonsumsi, sehingga dibutuhkan pengetahuan keuangan dalam membuat keputusan yang efektif sehingga dapat memperoleh utilitas maksimum dari produk yang dikonsumsi untuk meningkatkan kesejahteraan hidup.

Kata kunci: Perilaku konsumen; Literasi Keuangan; Pembuatan keputusan. 


\section{PENDAHULUAN}

Manusia identik dengan berbagai macam kebutuhan yaitu berupa barang ataupun jasa, hal ini disebabkan manusia ingin memenuhi setiap kebutuhannya dan mencari nilai kepuasan dari suatu produk yang dikonsumsi. Disebabkan perkembangan jumlah manusia yang diiringi dengan jumlah permintaan pemenuhan kebutuhan yang semakin meningkat, sedangkan alat pemuas kebutuhan jumlahnya tetap, maka manusia harus memilih dan memprioritaskan kebutuhan yang harus diutamakan. sehingga, menimbulkan beragam pilihan yang harus ditetapkan. diantara pilihan yang tersedia manusia dituntut mengambill keputusan yang tepat untuk dijadikan alternatif pilihan kebutuhan, yang tentunya efektif dan tepat guna.

Pengambilan keputusan harus didasarkan pada nilai dan manfaat dari suatu produk yang dipilih. Schiffman dan Kanuk mendefinisikan keputusan sebagai pemilihan suatu tindakan dari dua pilihan alternatif atau lebih, bagi seorang konsumen yang hendak memilih setiap pilihan yang tersedia seharusnya memiliki pilihan alternatif. Suatu keputusan tanpa adanya pilihan disebut pilihan Hobson
(Sangadji \& Sopiah, 2012). Menurut Setiadi inti dari pengambilan keputusan konsumen adalah proses pengintegrasian yang dikombinasikan pengetahuan untuk mengevaluasi dua perilaku alternatif atau lebih, dan memilih salah satu diantaranya. Hasil dari proses pengintegrasian ini merupakan suatu pilihan yang disajikan secara kognitif sebagai keinginan berperilaku (Sangadji \& Sopiah, 2012).

Sehingga Suatu keputusan konsumen harus didasarkan pada pengetahuan atau informasi tentang produk yang ada di pasaran yangakanmenjadipilihanalternatif.pengetahuan atau informasi mengenai suatu produk diperoleh dari pengalaman, berita, iklan, promosi dan kajian analisis akademik. Konsumen dalam pengambilan suatu keputusan sudah seharusnya didasarkan atas nilai kesyariahan. Pengambilan keputusan untuk menjalani hidup di dalam Islam telah diatur, mulai dari memilih sampai mengambil keputusan yang efisien dan memberi utilitas maksimum, sebab setiap tindakan akan dimintai pertanggung jawaban, oleh karena itu pengambilan sebuah keputusan yang tepat sangat dibutuhkan konsumen sehingga dalam pemenuhan kebutuhan dapat terpenuhi dan terdistribusi secara merata sesuai dengan skala 
prioritas kebutuhan, Salah satu faktor utama dalam pemenuhan prioritas kebutuhan sehingga membentuk prilaku konsumen yang baik adalah literasi keuangan (Budiwati, 2014).

Literasi keungan merupakan pengetahuan yang dimiliki oleh konsumen yang kemudian ikut menentukan proses pengambilan keputusan . Indonesia adalah salah satu negara yang sedang berkembang dan berupaya memperluas inklusi keuangannya. Hal ini merupakan upaya untuk menghilangkan segala bentuk hambatan terhadap akses masyarakat dalam memanfaatkan layanan jasa keuangan. Salah satu faktor berpengaruh terhadap keberhasilan upaya inklusi keuangan ini adalah tingkat literasi keuangan masyarakat. Literasi atau pengetahuan keuangan menunjukkan kemampuan atau tingkat pemahaman masyarakat tentang bagaimana uang bekerja (Said \& Amiruddin, 2016).

Survei yang dilakukan oleh Otoritas Jasa Keuangan (OJK) tahun 2013 menyimpulkan bahwa secara umum tingkat literasi keuangan masyarakat Indonesia baru mencapai 21,8\%, dengan tingkat utilisasi jasa keuangan sebesar 59,7\% (Wahana, 2014). Survei ini juga menunjukkan bahwa sektor perbankan mendominasi tingkat literasi dan utilisasi tersebut. Hal ini menunjukkan kondisi akses masyarakat Indonesia ke lembaga keuangan formal masih sangat rendah dibandingkan dengan negara-negara di Asia. Hasil survei ini juga didukung oleh Data Bank Dunia pada 2011 yang menyebutkan bahwa Indonesia (20\%) menempati urutan terendah dari enam negara Asia di kawasan Asia Tenggara dalam hal tingkat literasi keuangan masyarakatnya, dibanding Thailand (73\%), Malaysia (67\%), dan Filipina (27\%) (Margaretha \& Pambudhi, 2015). Di era ekonomi global saat ini, individu harus dapat mengelola secara cermat keuangannya. Karena dari pengelolaan keuangan tersebut akan menghasilkan keputusan dalam penggunaan ataupun mengalokasikan dana yang dimiliki. Agar keuangan dapat diolah secara cermat dan efisien, maka penting bagi individu untuk paham tentang literasi keuangan.

Penelitian yang relevan dilakukan oleh Ghaffar, (2014)menyatakan bahwa pengetahuan konsumen yang terdiri dari pengetahuan produk, pengetahuan pembelian , dan pengetahuan pemakaian mempunyai pengaruh positif dan signifikan terhadap keputusan nasabah dalam memilih Bank Syariah. 
Hasil pengujian pengukuran pengetahuan ekonomi yang dimiliki tidak mempengaruhi konsumen menunjukkan bahwa variabel yang perilaku dalam berkonsumsi. Sejalan dengan paling dominan memengaruhi keputusan hal tersebut (fattah, indriayu, \& sunarto, 2018; konsumen dalam memilih Bank Syariah di mawo, thomas, \& sunarto, 2017) mempunyai Makassar adalah pengetahuan pembelian, hal hasil riset yang sama bahwasanya literasi ini dikarenakan untuk variabel pengetahuan keuangan tidak berpengaruh terhadap perilaku pembelian mempunyai nilai koefisien regresi konsumsi dan menyatakan bahwakontrol diri terbesar serta memiliki nilai signifikan yang terkecil dari variabel pengetahuan produk dan pengetahuan pemakaian.

Penelitian lain yang dilakukan oleh Said \& Amiruddin, (2016) menyatakan bahwa terdapat perbedaan tingkat literasi keuangan syariah antara responden laki-laki dengan perempuan, dimana tingkat literasi keuangan syariah perempuan lebih tinggi daripada lakilaki, dari semua kelompok responden. Penelitian lain yang mendukung keberpengaruhan antara literasi keuangan terhadap perilaku konsumsi adalah Fauzia \& Nurdin, (2019); Pulungan \& Febriaty, (2018); Sari, (2015).

Riset lain yang menunjukan hasil yang berbeda yaitu (muaddab, 2015) temuanya menunjukkan bahwa literasi keuangan tidak berbengaruh terhadap perilaku konsumsi, selain itu status sosial ekonomi orang tua, ilmu yang mempelajari perilaku individu, pendidikan ekonomi keuangan dan sikap kelompok, atau organisasi dan proses - proses 
yang digunakan konsumen untuk menyeleksi, menggunakan produk, pelayanan, pengalaman (ide) untuk memuaskan kebutuhan dan keinginan konsumen, dan dampak dari proses- proses tersebut pada konsumen dan masyarakat. (2) Tindakan yang dilakukan oleh konsumen guna mencapai dan memenuhi kebutuhanya baik dalam penggunaan, maupun pemanfaatan barang dan jasa, termasuk proses keputusan yang mendahului dan yang menyusul. (3) Tindakan atau perilaku yang dilakukan konsumen yang dimulai dengan merasakan adanya kebutuhan dan keinginan, kemudian berusaha mendapatkan produk yang diinginkan, menggunakan produk tersebut, dan berakhir dengan tindakan-tindakan pasca pembelian, yaitu perasaan puas atau tidak puas. Sehingga Perilaku konsumen merupakan keputusan tindakan untuk memilih produk yang dilakukan manusia dalam memuaskan kebutuhan dengan sumberdaya yang tersedia (Nitisusastro, 2012).

Perilaku konsumen berupaya memenuhi setiap kebutuhan dan keinginan yang dialami setiap manusia, oleh karenanya dalam memenuhi kebutuhan tersebut manusia mencari produk yang dapat memberikan utilitas maksimum yang dapat di gunakan untuk menambah kesejahteraan hidupnya. Selanjutnya ketika individu tersebut melakukan konsumsi secara rutin maka akan membuat sebuah pola konsumsi dalam hidupnya dan menjadi sebuah kebiasaan ketika mengkonsumsi barang dan jasa. Aspek yang akan diguankan untuk mengetahui perilaku konsumen dalam penelitian ini adalah sebagai berikut : factor budaya yang didalamnya termasuk kebiasaan-kebiasaan yang ada pada keluarga dan lingkungan tempat tinggal; factor sosial yang meliputi referensi atau adanya kelompok acuan tertentu, keluarga dan status sosial; factor psikologi yang meliputi persepsi, pendidikan dan sikap dalam melakukan konsumsi.

Literasi keuangan merupakan suatu pengetahuan untuk memanajemen keuangan dan mengalokasikan seefektif mungkin dana yang dimiliki untuk mencapai kesejahteraan (Huston, 2010; Krishna, 2010; Margaretha \& Pambudhi, 2015; Mendari \& Kewal, 2013; Rasyid, 2012; Thomas \& Raymond, 2010), literasi keuangan juga merupakan proses mengukur seberapa baik individu dapat memahami dan menggunakan informasi 
keuangan pribadi. Seperti literasi pada umumnya mengkonseptualisasikan literasi keuangan sebagai dua dimensi, yaitu dimensi pemahaman ( pengetahuan mengenai keuangan pribadi ) dan dimensi penggunaan ( penerapan konsep dan produk keuangan pribadi ) (Ulfatun, 2016).

Sehingga ketika individu mempunyai wawasan keuangan yang cukup memadai dan mengaplikasikan kedalam kehidupan maka keseimbangan dan kesejahteraan hidup yang mudah untuk dicapai karena sudah termanajemen dengan baik dengan adanya literasi keuangan. Dalam penelitian ini, aspek yang digunakan untuk mengukur pengetahuan literasi keuangan adalah sebagai beriku : aspek pengetahuan tentang keuangan; pengetahuan tabungan dan pinjaman; aspek asuransi dan investasi.

Berdasarkan penjelasan diatas meliputi rangkaian teori dan penelitian terdahulu bahwa penelitian ini akan berfokus pada keberpengaruhan literasi keuangan terhadap perilaku konsumsi. Sehingga pembahasan akan melingkupi aspek pengetahuan tentang keuangan dan perilaku konsumsi.

\section{METODE PENELITIAN}

Metode yang digunakan dalam penelitian ini yaitu kuantitatif dengan teknik analisis regresi linier sederhana menggunakan data primer. Digunakan teknik purposive sampling pada populasi yang berjumlah 496 untuk menetapkan sampel penelitian yang didasarkan pada perhitungan yang dikemukakan oleh Slovin dan Husein Umar

$$
n=\frac{N}{\left(1+\left(\mathrm{N} \mathrm{x} \mathrm{e}^{2}\right)\right)}
$$

Berdasarkan perhitungan jumlah sampel yang diambil dalam penelitian ini yaitu 41 orang yang dapat merepresentatifkan populasi yang kemudian dilakukan beberapa uji kevalidan data dan uji analisis untuk mendapatkan sebuah kesimpulan. Diantara uji yang digunakan meliputi:

Uji Validitas Kuisioner ialah ketetapan atau kecermatan suatu instrumen dalam mengukur apa yang diukur. Data dikatakan valid jika pertanyaan pada kuesioner mampu mengungkapkan sesuatu yang diukur oleh kuesioner tersebut. Dalam melakukan uji validitas ini, peneliti akan menggunakan metode komputerisasi SPSS 23 dengan teknik pengujian bivariate pearson (Ghozali, 2016). Menentukan 
layak atau tidaknya suatu item yang akan digunakan, biasanya dilakukan uji signifikasi koefisien pada taraf signifikasi 0,05 . Artinya suatu item dianggap valid jika berkolerasi signifikan terhadap skor total atau instrument dinyatakan valid bila $\mathrm{r}$ hitung $>\mathrm{r}$ tabel.

Uji Reliabilitas Kuisioner adalah instrument untuk mengukur ketepatan, keterandalan, cinsistency, stability atau dependability terhadap alat ukur yang digunakan. Suatu alat ukur dikatakan reliabel atau dapat dipercaya, apabila alat ukur yang digunakan stabil, dapat diandalkan, dan dapat digunakan dalam peramalan. Artinya data yang dikatakan realibilitas adalah alat ukur yang digunakan bisa memberikan hasil yang sama walaupun digunakan berkali-kali oleh peneliti yang berbeda. Penelitian ini pengujian reliabilitas akan menggunakan program IBM SPSS 23. Untuk pengujian ini peneliti juga menggunakan batasan nilai sebesar 0,7. Jika nilai pada hasil reliabilitas kurang dari 0,7 maka hasil tersebut dikatakan tidak baik.

Metode Analisis digunkan uji asumsi klasik yang dilakukan untuk mengetahui hubungan antara data variabelyang digunakan. Ini perlu dilakukan sebelum melakukan uji analisis regresi terhadap variabel penelitian. $\mathrm{Uji}$ Normalitas bertujuan untuk menguji apakah dalam model regresi, variabel pengganggu atau residual memiliki distribusi normal (Ghozali, 2016). Variable penggangu dari suatu regresi disyaratkan berdistribusi normal, hal ini untuk memenuhi asumsi zero mean jika variable dan berdistribusi normal, maka variabel yang diteliti pada variable $\mathrm{Y}$ juga berdistribusi normal. Pengujian normalitas dilakukan dengan melihat nilai probability pada hasil uji normalitas dengan menggunakan Kolmogrov Smirnov untuk mengetahui apakah distribusi data pada tiap - tiap variabel normal atau tidak. Ketentuan suatu model regresi berdistribusi secara normal apabila probability dariKolmogrov Smirnov lebih besar dari $5 \%(\mathrm{p}>0,05)$.

Teknik Analisis Regresi Linier Sederhana merupakanMetode analisis data yang digunakan dalam penelitian ini adalah analisis regresi sederhana. Regresi sederhana berguna untuk meramalkan pengaruh dua variabel prediktor atau lebih terhadap satu variabel kreterium atau untuk membuktikan ada atau tidaknya hubungan fungsional antara dua buah variabel independen atau lebih dengan sebuah variabel dependen. Adapun Rumusnya adalah: 
$\mathrm{Y}=\mathrm{a}+\mathrm{b} \mathrm{X}+\mathrm{e}$

Uji T atau Uji Parsial dilakukan untuk pengujian secara parsial menggunakan uji $\mathrm{t}$ (pengujian signifikansi antara parsial). Langkah-langkah yang di tempuh dalam pengujian adalah: Menyusun hipotesis nol $\left(\mathrm{H}_{0}\right)$ dan hipotesis alternatif $\left(\mathrm{H}_{1}\right)$. Menetapkan kriteria pengujian yaitu:

$\mathrm{H}_{0}$ : diterima jika angka signifikansi lebih besar dari $\alpha=5 \%$

$\mathrm{H}_{0}$ : ditolak jika angka signifikansi lebih kecil dari $\alpha=5 \%$.

\section{HASIL DAN PEMBAHASAN}

Uji validitas digunakan untuk mengukur ketepatan suatu item dalam kuesioner atau skala yang ingin diukur. Validitas item ditunjukkan dengan adanya dukungan terhadap skor total. Dalam penentuan valid atau tidaknya item yang digunakan, kegiatan yang harus dilakukan adalah membandingkan $\mathrm{r}_{\text {hitung }}$ dengan $\mathrm{r}_{\text {tabel }}$, dimana taraf signifikansi yang digunakan adalah 0.05 dengan $\mathrm{N}=41$. Untuk mengetahui tingkat validitas tersebut, maka akan dilakukan terlebih dahulu perhitungan statistik dengan menggunakan program IBM SPSS Statistics 23. Berdasarkan perhitungan menggunakan bantuan SPSS 23 for windows secara keseluruhan item pernyataan pada variabel yang digunakan dapat dinyatakan valid karena seluruh item pernyataan memiliki nilai $r$ hitung yang lebih besar dari hasil $r$ tabel (0.308) atau $r$ hitung $>r$ tabel .

Uji reliabilitas dilakukan untuk mengetahui konsistensi alat ukur, apakah alat ukur yang digunakan dapat diandalkan dan tetap konsisten jika pengukurannya diulang. Dalam hal ini uji reliabilitas dilakukan dengan menggunakan metode Cronbach's Alpha, dengan kriteria bahwa tingkat alpha hitung lebih besar dari koefisien Alpha Cronbach sebesar 0,700 maka data yang diujikan memiliki tingkat reliabilitas yang baik. Adapun perhitungan tingkat alpha dilakukan dengan menggunakan program IBM SPSS Statistics 23. Hasil dari perhitungannya dapat terlihat pada tabel hasil output SPSS di bawah ini. Berdasarkan hasil uji reliabilitas variabel yang digunakan hasil menunjukkan lebih dari nilai koefisien Alpha Cronbach sebesar $(\mathrm{x}>0,700)$ maka dapat disimpulkan bahwa alat ukur dalam penelitian tersebut reliabel.

Uji Normalitas. Berdasarkan Tabel 1 hasil analisis data dengan menggunakan bantuan software SPSS 23. Variabel dinyatakan 
Tabel 1.

Hasil Uji Normalitas

One-Sample Kolmogorov-Smirnov Test

\begin{tabular}{clr}
\hline & & \multicolumn{2}{c}{ Unstandardized } \\
& & Residual \\
\hline $\mathrm{N}$ & & 41 \\
Normal Parameters & Mean & .0000000 \\
& Std. Deviation & 1.19180088 \\
Most Extreme Differences & Absolute & .136 \\
& Positive & .089 \\
& Negative & -.136 \\
Test Statistic & & .136 \\
Asymp. Sig. (2-tailed) & & $.055^{\mathrm{c}}$ \\
\hline
\end{tabular}

a. Test distribution is Normal.

Sumber: Data diolah

Tabel 2.

Hasil Analisis Regresi Linier Sederhana

\begin{tabular}{|c|c|c|c|c|c|}
\hline Model & \multicolumn{2}{|c|}{$\begin{array}{l}\text { Unstandardized } \\
\text { Coefficients }\end{array}$} & \multirow{2}{*}{$\begin{array}{c}\text { Standardized } \\
\text { Coefficients } \\
\text { Beta }\end{array}$} & \multirow[t]{2}{*}{$\mathrm{t}$} & \multirow[t]{2}{*}{ Sig. } \\
\hline & B & Std. Error & & & \\
\hline (Const.) & 1.828 & 1.237 & & 1.478 & .147 \\
\hline X & .933 & .046 & .955 & 20.110 & .000 \\
\hline
\end{tabular}

Sumber: Data diolah

terdistribusi normal jika hasil Kolmogorov

Smirnov test dengan menunjukkan nilai asymp.

sig. > alpha $(0,05)$. Pada tabel, dapat diketahui

bahwa nilai ujiKolmogorov Smirnov sebesar

0,136, sedangkan nilai asymp. sig. (2-tailed)

untuk unstandardized variable sebesar 0,055 ini dapat dilihat pada Tabel 2

lebih besar dari nilai $\alpha$ yaitu 0,05 , sehingga

dapat disimpulkan bahwa data yang digunakan

berdistribusi normal.
Analisis regresi sederhana digunakan untuk memprediksi atau menguji pengaruh satu variabel bebas atau variabel independent terhadap variabel terikat atau variabel dependent. Regresi sederhana dalam penelitian

Berdasarkan Tabel 2 uji regresi linier sederhana diatas dapat dijelaskan mengenai 
hubungan antar variabel terikat dengan atau 91,2\%. Dengan adanya nilai R Square variabel bebas. Dimana nilai $\mathrm{a}=1,828$, jika sebesar $91,2 \%$ berarti variabel independen nilai literasi keuangan sama dengan nol maka mempengaruhi variabel dependen sebesar perilaku konsumen adalah sebesar 1,828. 91,2\% sedangkan sisanya dipengaruhi oleh Adapun koefisien regresi variabel literasi variabel lain yang tidak dimasukan dalam model keuangan $(\mathrm{X})$ sebesar 0,933, artinya jika literasi Summary.

keuangan mengalami peningkatan sebesar $1 \%$ maka consumer behavior (Y) akan mengalami peningkatan sebesar 0,933\%. Koefisien bernilai positif berarti terjadi hubungan yang searah antara financial literacy dan consumer behavior, maka apabila nilai financial literacy meningkat maka nilai consumer behavior juga meningkat. Berdasarkan hasil data yang diperoleh pada tabel coefficient regresi sederhana, maka dapat diperoleh persamaan regresi sebagai berikut:

$$
\begin{aligned}
& \mathrm{Y}=\mathrm{a}+\mathrm{b} \mathrm{X}+\mathrm{e} \ldots \ldots \ldots \ldots \ldots \ldots \ldots \\
& \mathrm{Y}=1,828+0,933 \mathrm{X}+\mathrm{e} .
\end{aligned}
$$

Sedangkan pada Tabel 3 model summary dapat diketahui bahwa nilai $\mathrm{R}$ Square $=0,912$

Uji Parsial ( Uji t ) digunakan untuk mengetahui apakah dalam model regresi pada financial literacy berpengaruh signifikan terhadap consumer behavior. Hasil dalam pengujian ini dapat dilihat pada tabel 2 diatas. Sebelum menyimpulkan hipotesis yang diterima atau ditolak, terlebih dahulu menentukkan ttabel dengan signifikansi 5\%:2=2,5\% (uji 2 sisi) dan derajat kebebasan (df) $\mathrm{n}-\mathrm{k}-1$ atau 41$1-1=39$. Dengan pengujian dua sisi tersebut hasil yang diperoleh untuk ttabel sebesar 2,022. Sedangkan untuk thitung pada variabel financial literacy adalah 20,110.

Tabel 3.

Hasil Analisis Koefisien Determinasi

\begin{tabular}{llrrr}
\hline & & & & \multicolumn{2}{c}{$\begin{array}{c}\text { Std. Error of the } \\
\text { Estimate }\end{array}$} \\
\hline 1 & Model & R Square & Adjusted R Square & \\
\hline \hline
\end{tabular}

Sumber: Data diolah 
Berdasarkan hasil tersebut maka thitung pada variabel financial literacy lebih besar dari ttabel $(20,110>2.016)$, dan berdasarkan tingkat signifikansi lebih kecil dari $0,05(0,000<0,05)$ dapat disimpulkan bahwa Ho ditolak dan $\mathrm{Hi}$ diterima atau financial literacy berpengaruh terhadap consumer behavior secara signifikan.

Berdasarkan hasil pengujian dengan bantuan program SPSS 23 for windows dapat dinyatakan bahwa pengetahuan tentang keuangan mempunyai pengaruh yang signifikan terhadap perilaku konsumen di masyarakat. Hal tersebut menunjukkan bahwa pengetahuan masyarakat pada aspek keuangan telah tinggi dan pola konsumsi yang di aplikasikan pada masyarakat didasarkan pada pengetahuan keuangannya. sehingga disposible income yang diperoleh tidak dihabiskan untuk alokasi konsumsi seutuhnya namun ada sebagian yang didistribusikan untuk saving. Hal ini menunjukkan bahwa masyarakat telah sadar dan tidak terpengaruh dengan budaya konsumerisme yang menawarkan kegelamoran kehidupan. Masyarakat lebih memilih hidup cukup atau sekedar memenuhi kebutuhan dharuriyah yang diperlukan dalam hidup.
Penelitian ini mendukung riset sebelumnya yang dilakukan oleh Ghaffar, (2014); Said \& Amiruddin, (2016) dimana Masyarakat telah mengetahui seberapa banyak pendapatan yang di peroleh dan kebutuhan yang harus di penuhi. Sehingga masyarakat tidak mudah dipengaruhi adanya impulsive buying ketika membelanjakan untuk kebutuhan. Disisi lain masyarakat yang dihadapkan dengan aneka macam penawaran mulai dari diskon dan potongan harga lainnya sudah tidak dapat dipengaruhi, masyarakat telah memahami apa yang harus dipenuhi dalam kebutuhan bukan lagi keinginan yang tiada habisnya, dengan bekal informasi keuangan yang memadai dan tidak berlaku konsumtif.

Masyarakat lebih berprilaku hidup sederhana dan tidak boros terhadap apa yang dimilikinya. Sebagaimana Firman Allah dalam QS. Al Isra': 26-27 "Dan janganlah kamu menghambur-hamburkan (hartamu) secara boros. Sesungguhnya para pemboros-pemboros itu saudaranya syaitan.” Disisi lain menunjukkan perilaku berinvestasi atau niatan untuk berjagajaga juga telah di contohkan yaitu melalui hadis berikut : "Allah memberikan rahmat kepada seseorang yang berusaha mencari harta dengan jalan yang halal dan membelanjakannya 
dengan cara sederhana dan berhemat serta menabung kelebihannya untuk hari susah dan hajatnya." (HR. Muslim \& Ahmad). Sehingga pola konsumsi yang dijalankan yaitu pola konsumsi yang moderat dimana tidak hanya mementingkan apa yang harus dikonsumsi hari ini dan menghabiskan seluruh pendapatannya, namun lebih kepada apa yang dibutuhkan untuk di konsumsi dan disisihkan untuk alokasi jaga-jaga atau simpanan dan investasi untuk keperluan di masa mendatang.

\section{SIMPULAN DAN SARAN}

Simpulan yang dapat dikontribusikan dalam penelitian ini adalah didasarkan pada hasil uji regresi linier sederhana menunjukkan bahwa pengetahuan keuangan yang dimiliki oleh masyarakat meliputi pemahaman keuangan dan investasi menunjukkan hubungan positif terhadap perilaku konsumen dalam menentukan keputusan pada konsumsi. Penelitian ini memberikan bukti bahwa literasi keuangan juga menjadi salah satu factor penting dalam menentukan perilaku konsumsi seseorang.

Saran untuk penelitian selanjutnya, agar dapat mempertimbangkan hal berikut :
1) Sebaiknya menambah jumlah sampel tidak hanya satu wilayah atau komunitas saja, namun lebih luas lagi untuk mendapatkan kelengkapan data penelitian; 2) Penelitian selanjutnya dapat menambah jumlah variabel yang mempunyai pengaruh perilaku konsumen yang digunakan dalam penelitian; 3) penelitian berikutnya dapat menggunakan alat uji lain untuk menentukan model dalam penelitian yang lebih cocok.

\section{REFERENSI}

Budiwati, N. (2014). Analisis Literasi Ekonomi dan Perilaku Konsumen. UPI, Bandung.

Fattah, F. A., Indriayu, M., \& Sunarto. (2018). Pengaruh Literasi Keuangan dan Pengendalian Diri Terhadap Perilaku Konsumtif Siswa SMA Muhammadiyah 1 Karanganyar. Jurnal Pendidikan Bisnis Dan Ekonomi, 4(1), 11-21. http:// dx.doi.org/10 .20961/bise.v4i1.20 028

Fauzia, A. N., \& Nurdin. (2019). Pengaruh Literasi Keuangan terhadap Perilaku Konsumtif (Studi Kasus pada mahasiswa Program Studi Manajemen Universitas Islam Bandung angkatan 2015). Prosiding Manajemen, 5(1), 79 84.

Ghaffar, A. A. (2014). Pengaruh Pengetahuan Konsumen Terhadap Keputusan Nasabah Dalam Memilih Bank Syariah (Studi Kasus Nasabah Pada Bank Muamalat Cabang Makassar). UNHAS, Makasar.

Ghozali, I. (2016). Aplikasi Analisis Multivariate Dengan Program Ibm Spss 23, (08 ed.). Jakarta: Undip.

Huston, S. J. (2010). Measuring financial literacy. The Journal of Consumer Affairs, 44(2), 307-308.

Krishna, A. (2010). Analisis Tingkat Literasi 
Keuangan di Kalangan Mahasiswa dan Faktor-Faktor Yang Mempengaruhinya (Survey Pada Mahasiswa Universitas Pendidikan Indonesia). Proceedings of The 4th International Conference on Teacher Education; Join Conference UPI \& UPSI Bandung, 554. Bandung.

Margaretha, F., \& Pambudhi, R. A. (2015). Tingkat Literasi Keuangan pada Mahasiswa S-1 Fakultas Ekonomi Universitas Trisakti. Jurnal Manajemen Kewirausahaan, 17(1), 76-85. https:// doi.org/10.9744/jmk.17.1.76-85

Mawo, T., Thomas, P., \& Sunarto, St. (2017). Pengaruh Literasi Keuangan, Konsep Diri dan Budaya Terhadap Perilaku Konsumtif Siswa SMAN 1 Kota Bajawa. Journal of Economic Education, 6(1), 60-65.

Mendari, A. S., \& Kewal, S. S. (2013). Tingkat Literasi Keuangan Di Kalangan Mahasiswa STIE Musi Palembang. Jurnal Economia, 9(2).

Muaddab, H. (2015). Faktor yang Berpengaruh Terhadap Perilaku Konsumsi Hijau pada Siswa SMK Negeri Se-Kabupaten Jombang. Edusentris, Jurnal Ilmu Pendidikam Dan Pengajaran, 2(2), 126145.

Nitisusastro, M. (2012). Perilaku Konsumen dalam Perspektif Kewirausahaan. Bandung: Alfabeta.

Pulungan, D. R., \& Febriaty, H. (2018). Pengaruh Gaya Hidup dan Literasi Keuangan Terhadap Perilaku Konsumtif Mahasiswa. Jurnal Riset Sains Manajemen, 2(3), 103-110. https://doi. org/10.5281/zenodo.1410873

Rasyid, R. (2012). Analisis Tingkat Literasi Keuangan Mahasiswa Program Studi Manajemen Fakultas Ekonomi Universitas Negeri Padang. Jurnal Kajian Manajemen Bisnis, 1(2), 91.

Said, S., \& Amiruddin, A. M. A. (2016). Islamic Financial Literacy In Islamic Higher Education: Empirical Study At UIN Alauddin Makassar. 296. Bandar Lampung.

Sangadji, E. M., \& Sopiah. (2012). Perilaku Konsumen: Pendekatan Praktis. Yogyakarta: ANDI.

Sari, D. A. (2015). Financial Literacy dan
Perilaku Keuangan Mahasiswa (Studi Kasus Mahasiswa STIE YPPI Rembang). Buletin Bisnis Dan Manajemen, 01(02), 171-189.

Sugiyono. (2013). Metode penelitian kuantitatif dan kualitatif dan R\&G. Bandung: Alfabeta.

Thomas, E. G., \& Raymond, F. (2010). Personal Finance International Edition. Canada: South Western Cengage Learning.

Ulfatun, T. (2016). Analisis Tingkat Literasi KeuanganMahasiswaFakultas Ekonomi Universitas Negeri Yogyakarta Tahun Angkatan 2012-2014. Jurnal PELITA, 11(2), 4.

Wahana, A. (2014). Analisis Faktor-Faktor yang Mempengaruhi Perilaku Mahasiswa Dalam Menabung (Studi Kasus Mahasiswa S1 FEB UNDIP Tembalang). UNDIP, Semarang. 